\title{
The antibacterial effect of peritoneal fluid in experimental peritonitis
}

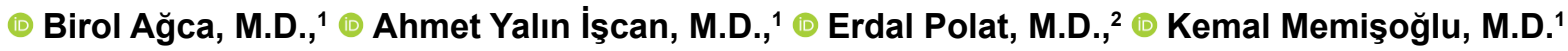

${ }^{1}$ Department of General Surgery, University of Health Sciences, İstanbul Fatih Sultan Mehmet Training and Research Hospital, İstanbul-Turkey ${ }^{2}$ Department of Microbiology, İstanbul University Cerrahpaşa Faculty of Medicine, İstanbul-Turkey

\begin{abstract}
BACKGROUND: In our study, the effects of peritoneal fluid on some Gram-negative and Candida albicans in experimental peritonitis rats were studied. The primary objective of the present study was to understand the effect of peritoneal fluid on microorganisms causing intra-abdominal infections.

METHODS: Twenty male Sprague-Dawley rats weighing between 250 and $300 \mathrm{~g}$ were used in the study. The rats were randomly divided into two groups consisting of 10 animals. The operative procedures were performed under sterile conditions. In group I, sham laparotomy was done. In group II, the distal part of the cecum was ligated, and cecum perforation was performed. Peritoneal fluid samples at baseline and 2 and $4 \mathrm{~h}$ were extracted using a Pasteur pipette during laparotomy under anesthesia.
\end{abstract}

RESULTS: Peritoneal fluid was ineffective on Citrobacter freundii, Proteus mirabilis, and Enterobacter aerogenes. It inhibited the growth of Klebsiella pneumoniae for $8 \mathrm{~h}$. However, growth was significantly increased in the passages obtained after $24 \mathrm{~h}$. The growth of $C$. albicans decreased in the passages that were extracted after 4 and $8 \mathrm{~h}$ and increased in the passages obtained after $24 \mathrm{~h}(\mathrm{p}<0.05)$. It was found that the number of Escherichia coli and Pseudomonas aeruginosa colonies that were grown in $2 \mathrm{~h}$ decreased, and no growth was detected in the passages obtained after $2 \mathrm{~h}(\mathrm{p}<0.05)$.

CONCLUSION: Proliferating colony counts of $E$. coli and $P$. aeruginosa decreased after $2 \mathrm{~h}$, and there was no proliferation in subsequent cultures. Peritoneal fluid exhibits a bactericidal effect under appropriate conditions. It also exhibits peritoneal bactericidal activity against $E$. coli, the major pathogen in intra-abdominal infections.

Keywords: Gram-negative bacteria; peritoneal defense; peritoneal fluid effects.

\section{INTRODUCTION}

The peritoneum is the largest serous membrane of the human body. It is a continuous transparent membrane that lines the abdominal cavity and covers the abdominal organs. It consists of two layers that are continuous with each other, the parietal peritoneum and the visceral peritoneum. They are both composed of a layer of simple squamous epithelial cells called mesothelium. The parietal peritoneum lines the internal surface of the abdominopelvic wall. The visceral peritoneum invaginates to cover the majority of the abdominal viscera. It is derived from the somatic mesoderm in the embryo. The visceral and parietal peritoneum have similar structural compositions consisting of three distinctive layers: mesothelium, basal lamina, and submesothelial stroma. The mesothelial membrane that lines the abdominal cavity is situated directly beneath the abdominal musculature and comprises a thin layer of loose connective tissue covered by a single layer of mesothelial cells. ${ }^{[1]}$

These membranes function to prevent friction between closely packed organs by secreting serum that acts as a lubricant, to help hold the abdominal organs in their proper positions, to separate and unite organs, and to act as a barrier against infection. The peritoneal cavity is a potential space between the parietal and visceral peritoneum. It contains a small

Cite this article as: Ağca B, İşcan AY, Polat E, Memişoğlu K. The antibacterial effect of peritoneal fluid in experimental peritonitis. Ulus Travma Acil Cerrahi Derg 2018;24:387-390.

Address for correspondence: Birol Ağca, M.D.

Fatih Sultan Mehmet Eğitim ve Araştırma Hastanesi, E5 Bostancı Mevki, Ataşehir, 34758 İstanbul, Turkey

Tel: +90216 - 5783000 E-mail: birolagca@yahoo.com

Ulus Travma Acil Cerrahi Derg 2018;24(5):387-390 DOI: 10.5505/tjtes.2018.10452 Submitted: 16.02.2018 Accepted: 16.07.2018 Online: 16.07.2018

Copyright 2018 Turkish Association of Trauma and Emergency Surgery 
amount of lubricating fluid. It also contains only a thin film of peritoneal fluid, consisting of water, electrolytes, leukocytes, and antibodies. The fluid plays two main functions: it acts as a lubricant, enabling free movement of the abdominal viscera, and its antibodies fight infection. Under healthy conditions, a small volume of $5-20 \mathrm{~mL}$ of peritoneal fluid is physiologically present in the peritoneal cavity. Peritoneal fluid contains various types of immune cells, such as macrophages, natural killer cells, lymphocytes, eosinophils, mesothelial cells, and mast cells. ${ }^{[2,3]}$ In pathological conditions, the balance between peritoneal fluid secretion and drainage is often disturbed, causing an accumulation of fluid in the peritoneal cavity known as ascites. $^{[1]}$

The peritoneal cavity contains resident and migratory cell populations, which play crucial roles in the local defensive response against bacterial invasion. The presence of bacteria in the peritoneal cavity triggers a number of local and systemic responses of the host not only aimed to fight the invading microorganisms but can also lead to deleterious local and systemic sequelae for the host.

Peritonitis can be divided into primary and secondary forms. Primary peritonitis occurs either spontaneously or secondary to infection of an intraperitoneal catheter, i.e., for dialysis. It is usually caused by a single organism. Secondary peritonitis is the sequelae of a perforation of the gastrointestinal tract caused by trauma or disease or secondary to the infection of an intra-abdominal organ. While primary peritonitis is caused by a single organism, the bacteriology of secondary peritonitis is more complex. The causative bacteria originate from the gastrointestinal tract, and therefore, secondary peritonitis is always a polymicrobial infection. ${ }^{[4]}$

Escherichia coli, Pseudomonas aeruginosa, Klebsiella pneumoniae, Citrobacter freundii, Proteus mirabilis, Enterobacter aerogenes, Bacteroides fragilis as Gram-negative bacteria, Staphylococcus aureus, Enterococcus faecalis, Propionibacterium species, Clostridium species, Peptococcus species as Gram-positive bacteria, and yeasts are counted as common pathogens causing peritoneal infections. $B$. fragilis and $E$. coli are common pathogens in intra-abdominal infection..$^{[5,6]}$

The aim of the present study was to assess the bactericidal and bacteriostatic effects of the peritoneal irrigation fluid of rats on $E$. coli, $P$. aeruginosa, $K$. pneumoniae, $C$. freundii, $P$. mirabilis, $E$. aerogenes, $B$. fragilis as Gram-negative bacteria, and Candida albicans.

\section{MATERIALS AND METHODS}

A total of 20 male Sprague-Dawley rats weighing between 250 and $300 \mathrm{~g}$ were used in the present study. The animals were supplied by the Laboratory of Microbiology of the Cerrahpasa Medical Faculty of the Istanbul University. The rats were housed in standard cages under standard laboratory conditions with unrestricted access to a balanced pellet diet and water.

The study protocol was approved by the Ethics Committee for Animal Experimentation of Istanbul University Cerrahpasa Medical Faculty (Istanbul, Turkey), and the experiments were conducted in accordance with animal protection laws.

The animals were randomly assigned into two groups: the sham laparotomy group (group I) and the cecal ligation + perforation group (group II). After adaption, bacterial peritonitis was induced using the cecal ligation and puncture model. The animals were anesthetized by subcutaneous injection of a combination of $25 \mathrm{mg} / \mathrm{kg}$ of ketamine hydrochloride (10\% ketamine; Sanofi-Ceva GmbH, Düsseldorf, Germany) and 5 $\mathrm{mg} / \mathrm{kg}$ of xylazine hydrochloride (2\% Rompun; Bayer AG, Leverkusen, Germany). After weighing, shaving, and disinfecting the skin, a $3 \mathrm{~cm}$ midline incision was made. The cecum was filled with feces and ligated just below the ileocecal valve with a 3-0 polyglactin suture, permitting bowel continuity. The antimesenteric cecal wall was punctured with a 21 -gage needle, and the bowel was replaced into the abdominal cavity. Peritoneal fluid samples were collected for microbiological examination. The rats in both groups were then subjected to relaparotomy in sterile conditions at 2 and $4 \mathrm{~h}$, respectively. Peritoneal lavage with $\mathrm{I} \mathrm{ml}$ of isotonic sodium chloride solution saline was repeated, and peritoneal fluid samples were extracted.

\section{Peritoneal Fluid}

Peritoneal lavage was performed by allowing $\mathrm{I} \mathrm{ml}$ of sterile saline into the peritoneal cavity using a Pasteur pipette. The fluid was collected by centrifuge tubes. The cells obtained from peritoneal lavage fluid were placed on a $1 \mathrm{~cm} 3$ area of Thoma and guiding slides. The cells were stained with Giemsa and then counted. Total peritoneal cells and phagocytes were counted (cells $/ \mathrm{ml}$ ). The phagocytic cells were classified, and their percentage was calculated on Giemsa-stained slides. The fluid samples extracted at 0,2 , and $4 \mathrm{~h}$ were centrifuged, then passed through a Seitz filter (pore diameter $200 \mathrm{~nm}$ ), and sterilized. A $0.1 \mathrm{ml}$ of fluid containing 104 microorganisms per milliliter and $0.9 \mathrm{ml}$ of filtered peritoneal fluid were mixed in a tube. The passages from this solution were inoculated into Mueller-Hinton agar at 0, 2, 4, and 24 h. The inoculates were spread over the surface of agar plates in a standard pattern, so that the quantity of bacterial growth could be determined either semi-quantitatively or relatively. After each culture was incubated at $37{ }^{\circ} \mathrm{C}$ for $48 \mathrm{~h}$, the number of proliferating colonies was counted. The bacteriostatic and bactericidal effects of the peritoneal fluid on microorganisms were assessed. This procedure was repeated for each microorganism, and the fluid was extracted from the peritoneal cavity at 0,2 , and $4 \mathrm{~h}$. Control cultures were performed for each group. 
Table I. Bactericidal effects of the peritoneal fluid samples obtained from all rats at different time points

\begin{tabular}{lccccc}
\hline Microorganisms & $\mathbf{0}$ & $\mathbf{2}$ & $\mathbf{4}$ & $\mathbf{8}$ & $\mathbf{2 4}$ \\
hour & hour & hour & hour \\
\hline Escherichia coli & 330 & 45 & - & - & - \\
Pseudomonas aeruginosa & 420 & 124 & - & - & - \\
Klebsiella pneumoniae & 330 & 100 & 90 & 95 & 500 \\
Candida albicans & 252 & 184 & 50 & 30 & 140 \\
\hline
\end{tabular}

\section{Microbiology}

After culturing for $18 \mathrm{~h}$ in tryptic soy broths, E. coli, K. pneumoniae, $E$. aerogenes, $C$. freundii, $P$. aeruginosa, $P$. mirabilis, and $C$. albicans were isolated from feces. The microorganisms were inoculated after dilution to $104 / \mathrm{ml}$ using several culture techniques.

\section{Statistical Analysis}

For comparison of intragroup and intergroup results, Student's t-test and ANOVA were used, respectively. A p value $<0.05$ was considered as statistically significant.

\section{RESULTS}

\section{Bactericidal Activity of Peritoneal Cells}

In all groups, the peritoneal fluid was not effective against $P$. mirabilis, $E$. aerogenes, and $C$. freundii. In addition, it was observed that the proliferation of $K$. pneumoniae stopped for $8 \mathrm{~h}$. However, it was determined that proliferation in cultures increased after $24 \mathrm{~h}$. A decrease in proliferation was observed in C. albicans at the end of 4 and $8 \mathrm{~h}$, and an increase in proliferation was seen at the end of $24 \mathrm{~h}$. It was also observed that the proliferating colony counts of $E$. coli and $P$. aeruginosa decreased after $2 \mathrm{~h}$, and there was no proliferation in subsequent cultures (Table I, Fig. I).

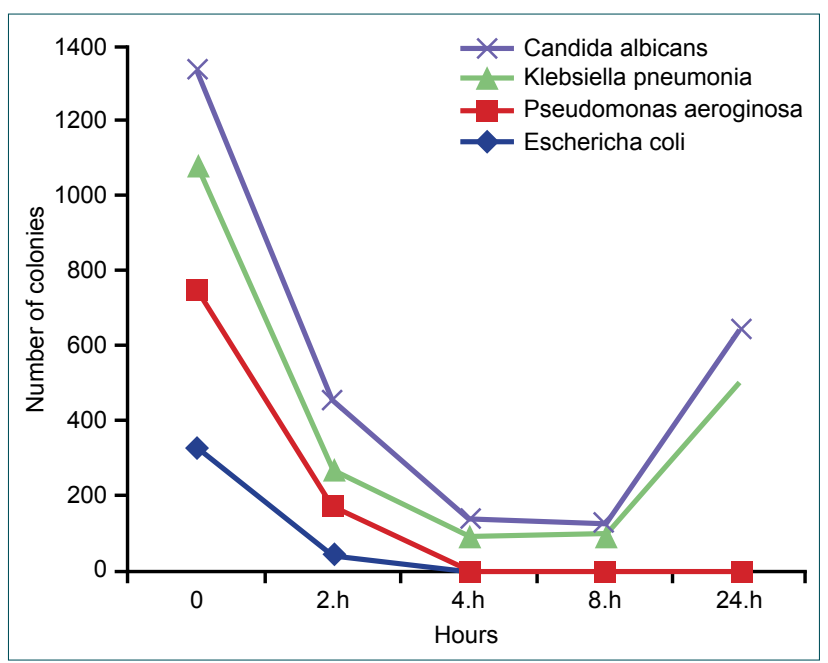

Figure 1. Number of colonies of microorganisms at different time points.

\section{DISCUSSION}

Peritoneal infections may be mainly due to: (I) translocation of microorganisms from exogenous or endogenous flora to the sterile sides in the body as a result of organic traumas or injuries that break dermal or mucosal barriers mechanically; (2) surgical contamination, infections due to biomaterials, antimicrobial medication, or chemotherapy leading to hemostatic imbalance between the host and the commensal microflora of the host; and (3) bacterial translocation through the intact mucosal barrier of the intestines. It is known for years that anaerobic bacteria may lead to peritoneal infections. It was recorded that $37 \%$ of peritoneal infections are due to Bacteroides species; $57 \%$ are due to facultative anaerobic and aerobic Gram-negative bacilli of which $36 \%$ is E. coli alone. ${ }^{[7,8]}$ In one study by Uzunköy et al., ${ }^{[9]} \mathrm{E}$. coli was produced in all subjects in lymphoid tissue cultures in rats with bacterial peritonitis, and in addition, $P$. mirabilis and $K$. pneumoniae were observed.

Lipopolysaccharides in the bacterial walls, yeasts (Candida, Cryptococcus, etc.), some tumor cells, parasites, and viruses activate the components of the complement system that institutes a chemotactic gradient for the polymorphonuclear leukocytes (PMNLs). The migration to the peritoneal cavity due to chemotactic factors starts in $30 \mathrm{~min}$ and reaches a maximum rate at $72 \mathrm{~h}$. The number of peritoneal cells was counted in Thoma slides. The peak number was achieved at 6 $\mathrm{h}$, and this number did not increase at $9 \mathrm{~h}$; however, a decrease was recorded as time passed. Accordingly, the peritoneal fluid extracted at $6 \mathrm{~h}$ following the stimulation of the peritoneal membrane was preferred in the present study. Phagocytosis is a rapid response allowing approximately $3 \%$ of the bacteria to be unbound after $2 \mathrm{~h}$ post-inoculation. ${ }^{[7]}$ Although macrophages are the primary phagocytic cells, PMNLs are the earliest set of cells drawn into the peritoneal cavity. ${ }^{[10]}$

Phagocytosis is triggered by nonspecific opsonins, such as complements, fibronectin, or specific antibodies present in the peritoneal fluid. Complements play an important role of body defense in the early phase of infections where antibodies are not formed yet. ${ }^{[\prime]}$ Lysozymes break the bonds between $\mathrm{N}$-acetylmuramic acid and $\mathrm{N}$-acetylglucosamine in Gram-positive bacteria. The peptidoglycan and muramic acid present in the cell walls of Gram-negative bacteria are protected by an outermost membrane, thus the effect of lysozyme being minimum. ${ }^{[2]}$ Histamine and other vasoactive substances released from peritoneal mast cells cause dilation of the capillaries in the peritoneal cavity. An increased permeability leads to an accumulation of fluid rich in complements, immunoglobulins, fibrins, and thrombotic factors. Bergman et al. ${ }^{[13]}$ reported that cell-free amniotic fluid obtained from 28 healthy women is effective on Gram-negative and Gram-positive bacteria and yeasts. This bacteriostatic or bactericidal effect might depend on complements, thermostability, and maybe some other factors since lysozyme in the amniotic fluid solely cannot be responsible for the antimicrobial activity. In a study comparing the antibacterial activity of peritoneal fluid obtained from 28 women who underwent laparoscopy with the acid fluid obtained from II patients with various pathological conditions, 
the bactericidal and bacteriostatic activities in both types of lavage were predominantly against Gram-negative bacilli- $E$. coli, P. mirabilis, and B. fragilis. ${ }^{[14]}$

In our study, we found that peritoneal fluid had no effect on $C$. freundii, $P$. mirabilis, and $E$. aerogenes; however, peritoneal fluid was found to be bactericidal for $E$. coli and $P$. aeruginosa and bacteriostatic for $K$. pneumoniae and $C$. albicans. The cells and substances in the peritoneum prevent bacterial contamination and peritoneal inflammation. The main target in managing peritonitis is to control sepsis and eliminate contamination sources. The contamination of the peritoneal cavity with bacteria can be via endogenous route or exogenous route. The mortality of peritonitis is still high despite advances in medicine. Overall, mortality in secondary peritonitis varies between $13 \%$ and $18 \%$ and between $0 \%$ and $46 \%$ according to contamination source and age, respectively. Control of sepsis and removal of contamination sources and peritoneal debris are the principal goals of peritonitis treatment. Removing or decreasing the debris is possible using peritoneal lavage that can be performed in several ways. There is no doubt on the importance of sepsis and removal of the contamination source. However, the effectivity of peritoneal lavage in the management of peritonitis is rather doubtful. It is accepted that short-term peritoneal lavage is useful in the treatment of peritonitis as it decreases the microbial load. ${ }^{[15]}$

In the present study, the bactericidal activity of the peritoneal fluid decreases due to peritoneal lavage in the early phase and returns to normal after $4 \mathrm{~h}$. The bactericidal effect of the peritoneum should be taken into consideration, and it is necessary to prevent the disruption of the peritoneal defense mechanism. We can claim that continuous or intermittent peritoneal lavage will not be beneficial. On the other hand, it cannot disrupt the protective mechanisms as the bactericidal activity of the peritoneum is considered to be important in the early phases of peritonitis.
Conflict of interest: None declared.

\section{REFERENCES}

1. Capobianco A, Cottone L, Monno A, Manfredi AA, Rovere-Querini P. The peritoneum: healing, immunity, and diseases. J Pathol 2017;243:137-47.

2. Van Baal JO, Van de Vijver KK, Nieuwland R, van Noorden CJ, van Driel WJ, Sturk A, et al. The histophysiology and pathophysiology of the peritoneum. Tissue Cell 2017;49:95-105. [CrossRef]

3. Gazvani R, Templeton A. Peritoneal environment, cytokines and angiogenesis in the pathophysiology of endometriosis. Reproduction 2002;123:217-26. [CrossRef]

4. Hau T. Peritoneal Defense Mechanisms. Turk J Med Sci 2003;33:131-4.

5. Swenson RM, Lorber B, Michaelson TC, Spaulding EH. The bacteriology of intra-abdominal infections. Arc Surg 1974;109:398-9. [CrossRef]

6. Swenson RM, Lorber B. Clindamycin and Carbenicillin in treatment of patients with intraabdominal and female genital tract infections. J Infect Dis 1977;135 Suppl:S40-5. [CrossRef]

7. Baron EJ, Fniegold SM. Bailey and Scott's Diagnostic Microbiology. 8th ed. Missouri: C.V. Mosby; 1990. p. 363-407.

8. Koneman EW, Allen SD, Janda WM, Schreckenberg PC, Winn WC. Diagnostic Microbiology. 5 th ed. New York: Lippincott; 1997.p. 171-309.

9. Uzunköy A, Ozbilge H, Horoz M. The influence of omentectomy on bacterial clearance: an experimental study. Ulus Travma Acil Cerrahi Derg 2009; 15:541-5.

10. Kuraoka S, Campeau JD, Nakamura RM, diZerega GS. Modulation of postsurgical macrophage function by early postsurgical polymorphonuclear leukocytes. J Surg Res 1992;53:245-50. [CrossRef]

11. Pascual M,French LE. Complement in human diseases: looking towards the 21st century. Immunol Today 1995;16:58-61. [CrossRef]

12. Bernard E, Rolain T, Courtin P, Guillot A, Langella P, Hols P, et al. Characterization of $\mathrm{O}$-acetylation of $\mathrm{N}$-acetylglucosamine: a novel structural variation of bacterial peptidoglycan. J Biol Chem 2011;286:23950-8.

13. Bergman N, Bercovici B, Sacks T. Antibacterial activity of human amniotic fluid. Am J Obstet Gynecol 1972;114:520-3. [CrossRef]

14. Michel J, Bercovici B, Sacks T. Comparative studies on the antimicrobial activity of peritoneal and ascitic fluids in human beings. Surg Gynecol Obstet 1980;151:55-7.

15. Sayek I, Abbasoğlu O, Altaca G, Akalın E. The effect of peritoneal lavage on survival in experimentalfecal peritonitis and peritoneal fluid bactericidal activity. Surg Res Comm 1990;7:277-82.

\section{DENEYSEL ÇALIŞMA - ÖZET}

\section{Deneysel peritonitte peritoneal sıvının antibakteryel etkisi}

\section{Dr. Birol Ağca, ${ }^{1}$ Dr. Ahmet Yalın İşcan, ${ }^{1}$ Dr. Erdal Polat, ${ }^{2}$ Dr. Kemal Memişoğlu ${ }^{1}$}

${ }^{1}$ İstanbul Sağlık Bilimleri Üniversitesi Fatih Sultan Mehmet Eğitim ve Araştırma Hastanesi, Genel Cerrahi Kliniği, İstanbul 2̇istanbul Üniversitesi Cerrahpaşa Tıp Fakültesi, Mikrobiyoloji Anabilim Dalı, İstanbul

AMAÇ: Çalışmamızda deneysel peritonit oluşturulan sıçanlarında, periton sııısının bazı gram negatif ve Candida albicans üzerine olan etkisi araştırıldı. Çalışmanın temel amacı karın içi enfeksiyonlara neden olan mikroorganizmalar üzerine periton sıvısının etkisini anlamaktır. GEREÇ VE YÖNTEM: Bu çalışmada 250-300 g ağıllı̆ında 20 erkek Spraque-Dawley sıçanı kullanıldı. Sıçanlar rastgele 10 hayvandan oluşan iki gruba ayrıldı. Ameliyat prosedürleri steril koşullar altında yapıldı. Grup l'de kontrol laparotomisi yapıldı. Grup Il'de çekumun distal kısmı bağlandı ve çekum perforasyonu yapıldı. Deneklerden 2. ve 4. saatte anestezi altında laparotomi yapılarak peritoneal sıvı örnekleri Pasteur pipet kullanılarak alındı. BULGULAR: Periton SIVISI, C. freundii, P. Mirabilis ve E. aerogenes'e etkisizdi. Sekiz saat boyunca K. pneumoniae üremesini engelledi, ayrıca 24 saat sonra alınan pasajlarda büyüme önemli ölçüde arttığı görüldü. C. Albicans üremesi ise 4 ve 8 saat sonra alınan pasajlarda azaldı ve 24 saat sonra ise arttı. E. coli ve P. aeroginosa kolonilerinin sayısının 2 saat sonraki alınan pasajlarda artmadığı ve üreme olmadığı saptandı.

TARTıŞMA: E. coli ve P. aeruginosa'nın çoğalan koloni sayıları 2 saat sonra azaldı ve sonraki kültürlerde çoğalma yoktu. Periton sıvısı, uygun koşullar altında bakterisidal bir etki gösterir. Karın içi enfeksiyonlarda ana patojen olan E. coli'ye karşı peritoneal bakterisidial etkinlik göstermektedir. Anahtar sözcükler: Gram-negatif bakteri; peritoneal savunma; periton sıvısı. 